九州大学学術情報リポジトリ

Kyushu University Institutional Repository

\title{
Soil Erosion and Sediment Disaster in Nepal-A Review
}

Joshi, Jagannath

Laboratory of Soil and Water Conservation, Faculty of Agriculture, Kyushu University

Bhattarai, Tara Nidhi

Environmental Geomechanics Division, Faculty of Engineering, Kyushu University

Sthapit, Keshar Man

Ministry of Forests and Soil Conservation

Omura, Hiroshi

Laboratory of Soil and Water Conservation, Faculty of Agriculture, Kyushu University

https://doi.org/10.5109/24237

出版情報 : 九州大学大学院農学研究院紀要. 42 (3/4), pp.491-502, 1998-03. Kyushu University バージョン：

権利関係 : 


\title{
Soil Erosion and Sediment Disaster in Nepal-A Review
}

\author{
Jagannath Joshi*, Tara Nidhi Bhattarai**, Keshar Man Sthapit*** \\ and Hiroshi Omura*
}

\author{
* Laboratory of Soil and Water Conservation, Faculty of Agriculture \\ ** Environmental Geomechanics Division, Faculty of Engineering \\ Kyushu University, Fukuoka 812-8581, Japan \\ *** Ministry of Forests and Soil Conservation, Kathmandu, Nepal \\ (Received September 22, 1997 and accepted December 3, 1997)
}

\begin{abstract}
Nepal is very prone to soil erosion and is susceptible to sediment disasters mainly caused by slope failure, landslides, debris flows and bank erosion. Fertility of the soil or productivity of the land is deteriorating due to accelerated surface soil erosion. At the same time, sediment disasters annually destroy or damage residential areas, agricultural land with crops and development infrastructures. Magnitude and effects of these geomorphic processes are very high due to the fragile geology, steeply sloping rugged mountain topography, anomalous climatic conditions and human activities.

Urgent need of accelerated erosion control and prevention of potential sediment disasters is realised and various soil conservation measures and watershed management programs have been implemented for this purpose. But, the problems are still critical. Soil erosion or sediment disasters due to natural processes are likely to continue into the future also but, human contribution in accelerating these processes can be minimized. Very limited research works, lack of économically feasible appropriate technology, inappropriate land use and insufficient resources are main problems implementing erosion control and sediment disaster prevention counter measures. International cooperation is expected in the research, appropriate technology transfer and human resource development to develop Nepal as a less hazardous country in the future.
\end{abstract}

\section{INTRODUCTION}

Nepal is a mountainous country, situated between the latitude of $26^{\circ} 22^{\prime}$ to $30^{\circ} 27^{\prime}$ north and longitude of $80^{\circ} 04^{\prime}$ to $88^{\circ} 12^{\prime}$ east. It is sandwiched between China in the north and India in the east, west and south. The kingdom of Nepal occupies nearly the middle one third of the $2,400 \mathrm{~km}$ long Himalaya and its foothills. Its total area is 147 , $181 \mathrm{~km}^{2}$. Its average length from east to west is $870 \mathrm{~km}$ and its width varies from 130 to $260 \mathrm{~km}$ from north to south. In altitude it ranges from ca. $70 \mathrm{~m}$ above sea level in the southeastern plain to $8,848 \mathrm{~m}$ at the summit of Mt Everest. The country is drained by four major river systems and more than 6,000 tributaries.

There is great variety in the topography of Nepal, causing diverse climatic conditions. About $83 \%$ of the country is mountainous terrain and remaining $17 \%$ in the south lies in the alluvial plains. The country experiences a wide range of climate from tropical to alpine. Temperature decreases from south to north and with increasing altitude. The annual mean maximum temperature is about $40^{\circ} \mathrm{C}$ that prevails in the southern plain of the western Nepal in hot season, and falls below $0^{\circ} \mathrm{C}$ in the snow clad mountains of the northern region. 
The average annual precipitation in Nepal is ca. $1,530 \mathrm{~mm}$. The variation ranges from $300 \mathrm{~mm}$ north of the Himalaya, to about $5,000 \mathrm{~mm}$ in central Nepal. Sixty to $80 \%$ of annual rainfall fall during the monsoon season from June to September.

According to the census in 1991, population of Nepal is $18,491,097$ with an annual growth rate of $2.08 \%$. About $91 \%$ of the population derive their livelihood from agriculture and related activities (CBS, 1994).

Kobayashi et al. (1995) have stated that Nepal has the highest level of natural disasters. But investigations on natural hazards are insufficient. According to Bhatta (1993), soil erosion is probably the most serious resource conservation problem. Nepal is loosing approximately 240 million $\mathrm{m}^{3}$ soil annually, which is equal to $1.6 \mathrm{~mm}$ of soil removed from the entire surface of the country.

The purpose of this report is to discuss the causes and consequences of soil erosion and sediment disaster in Nepal. Since erosion and sedimentation occur as a combined result of various natural factors, a brief account of physiography, geology, land use and vegetation is given as background information. In addition, the relationship between Himalayan geomorphology and sediment disasters is discussed in brief.

\section{PHYSIOGRAPHY}

Land Resource Mapping Project (LRMP, 1986) has identified five physiographic zones of Nepal (Figure 1). These zones are schematically shown in Figure 2 and main characteristics are outlined in Table 1.

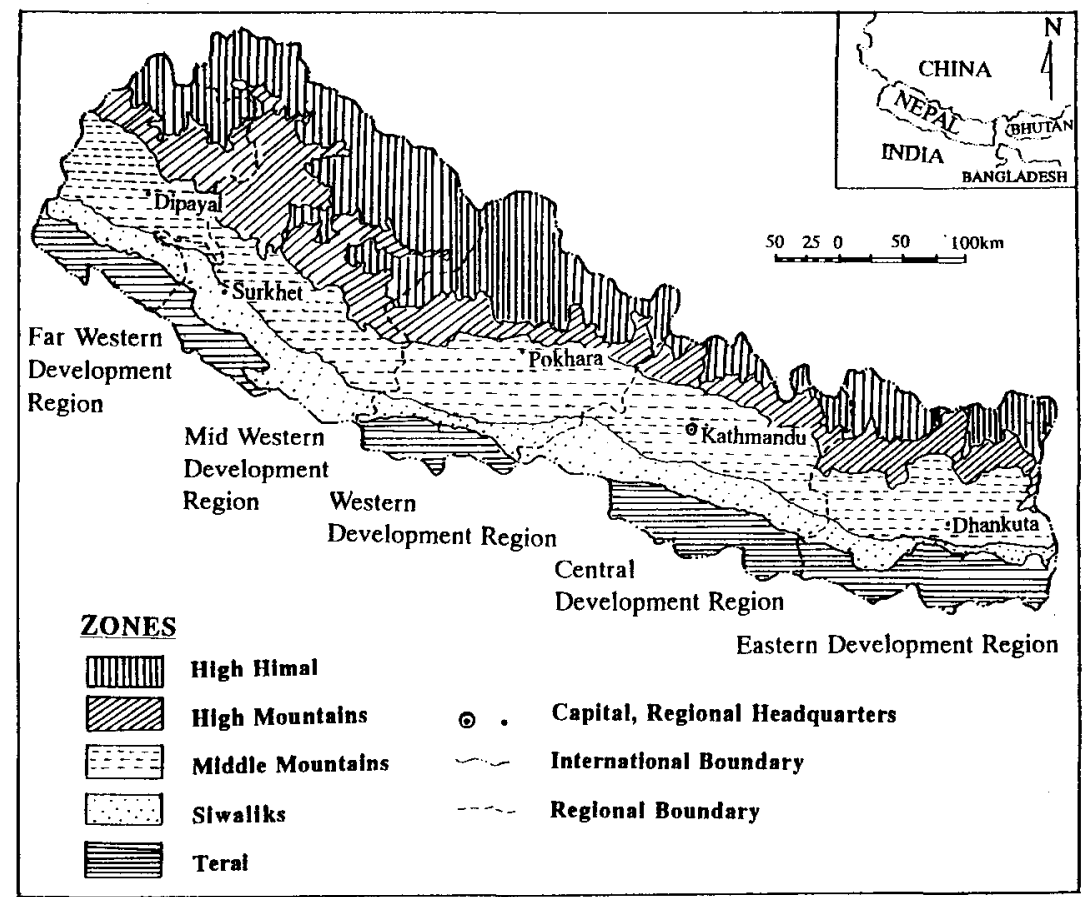

Fig. 1. Location and physiographic map of Nepal (Department of Survey, His Majesty's Government of Nepal, 1985). 


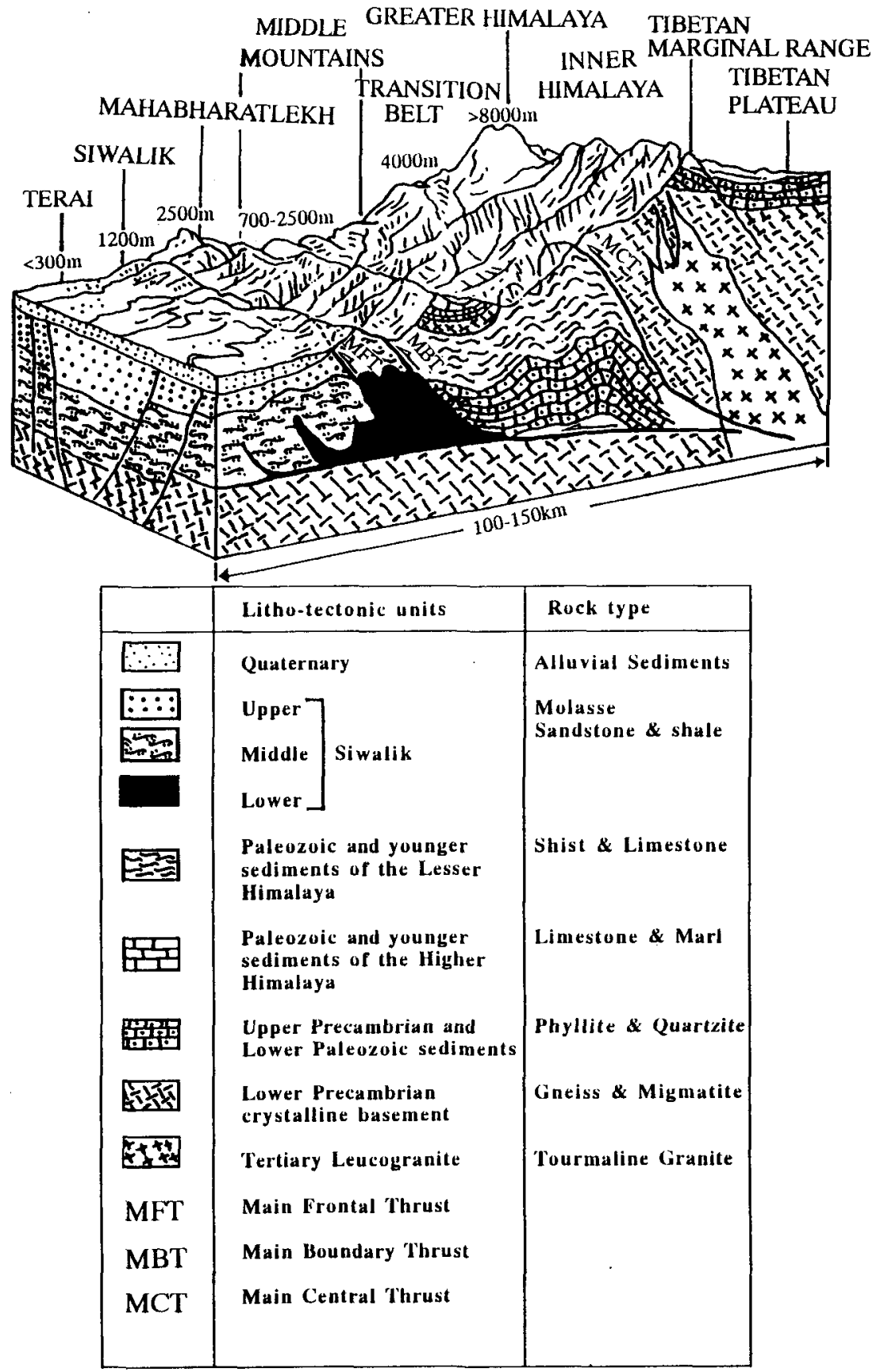

Fig. 2. Schematic cross-section of the Nepal Himalaya (Modified after W. J. H. Ramsay, 1986). 
Table 1. Physiographic Zones of Nepal

\begin{tabular}{|c|c|c|c|}
\hline Physiographic Zone & Elevation (m) & Area (\%) & Remarks \\
\hline High Himal & $4,000-8,848$ & 23 & $\begin{array}{l}\text { Mostly snow massifs, snow fields, } \\
\text { valley glaciers, meadow land and } \\
\text { rocks. } \\
\text { Kept in a natural state. }\end{array}$ \\
\hline High Mountains & $2,300-4,000$ & 20 & $\begin{array}{l}\text { Mostly forested, sparsely } \\
\text { populated and less disturbed. }\end{array}$ \\
\hline Middle Mountains & $\begin{array}{l}\text { up to } 3,000 \\
\text { lowest river } \\
\text { bottom is less } \\
\text { than } 500 \text { (east) }\end{array}$ & 30 & $\begin{array}{l}\text { Lower elevation varies greatly } \\
\text { from east to wast. } \\
\text { Densely inhabited and, } \\
\text { intensively cultivated. } \\
\text { Large number of slope } \\
\text { failure/landslide scars and } \\
\text { deforested land exist. }\end{array}$ \\
\hline Siwaliks & $300-1,500$ & 13 & $\begin{array}{l}\text { Extremely fragile nature of } \\
\text { soil/rock and very erodible. } \\
\text { Gullies and slope failure are } \\
\text { frequent. }\end{array}$ \\
\hline Terai & $\begin{array}{l}\quad 70-300 \\
\text { (Bhabar subzone } \\
\text { of Terai is up to } 500 \text { ) }\end{array}$ & 14 & $\begin{array}{l}\text { Gangetic alluvial plain. } \\
\text { Most productive land for } \\
\text { agriculture. } \\
\text { Frequent flood and sediment } \\
\text { deposition on cultivated land is a } \\
\text { serious problem. }\end{array}$ \\
\hline
\end{tabular}

1. High Himal: The High Himal zone lies between the upper limit of forest vegetation and crests of the Himalayas. This area occupies $23 \%$ of the country. The highest point is Mt Everest at $8,848 \mathrm{~m}$. There are seven other peaks above $8,000 \mathrm{~m}$ in this zone. Many great rivers of Nepal originate from north of the main Himalayan chain and cross it in deep gorges, creating a number of separate massifs. About $21,000 \mathrm{~km}^{2}$ of this area is under permanent ice and snow, and much of the rest is poor grazing land, usable only in summer months. Naturally this zone is very sparsely inhabited.

2. High Mountains: The High Mountain zone lies between the heavily populated Middle Mountains and the High Himal. Its upper boundary is the forest line at about $4,000 \mathrm{~m}$. Its lower boundary is a somewhat diffuse line at about 2,300 to $3,000 \mathrm{~m}$ along ridges, but as low as $1,000 \mathrm{~m}$ in river valleys. This zone occupies $20 \%$ of the country.

3. Middle Mountains: The Middle mountains zone is the great central belt of Nepal which occupies about $30 \%$ of the country. Upper boundary of this zone is $3,000 \mathrm{~m}$ along 
mountain ridge. The lowest parts are the river bottom lands in the east at about $200 \mathrm{~m}$. It is composed of a network of ridges and valleys; less than $5 \%$ is flat land. Land of this zone is intensively used by the people and inevitably there are a large number of slope failures, landslide scars, gullies and deforested land.

4. Siwaliks (or Churiya Hills): The Siwaliks zone lies between Middle Mountains in the north and Terai in the south. Siwaliks have been formed from sediments produced by the raising Himalaya. These sediments are soft and very erodable, and for this reason, there are a number of gullies, landslides and areas of bad-land throughout this zone. The zone occupies $13 \%$ of the country, with a lower boundary at $300 \mathrm{~m}$ elevation and upper boundary along ridges at 500 to $700 \mathrm{~m}$ in the east, and up to $1,500 \mathrm{~m}$ in the west. Soils of this zone are comparatively dry and by nature, are extremely fragile.

5. Terai: This zone is bounded on the north by the first ridge of the Siwaliks and its southern boundary is the Indian border. It is a plain area whose elevation ranges from $70 \mathrm{~m}$ to $300 \mathrm{~m}$ with a gentle southward slope of less than one percent. The Bhabar subzone of Terai extends up to $500 \mathrm{~m}$. Terai covers about $14 \%$ of the country. The Terai is being developed for agriculture and industry, so there is heavy pressure on its land and forest resources. Each year, flood and sediment deposition on cultivated land cause loss of life and property.

\section{GEOLOGY}

The geology of Nepal is governed by a complex sequence of events which resulted in the high elevation of the Himalaya. About 40 millions years ago, at the end of the Mesozoic era the Indian plate collided with the Asian plate squeezing sedimentary rocks of the old Tethys Sea into folded mountains. This folding metamorphism and subsequent erosion has produced a complicated geology with different types of rocks over very short horizontal distances in the north-south direction. The mountains and hills thus formed are young, unconsolidated, and fragile due to tectonic activity in the course of the orogenic movement.

Geologically, Nepal Himalaya is subdivided into the following five major tectonic zones from north to south, respectively (Ganser, 1964). These tectonic zones (or geological divisions) roughly correspond to the physiographic zones as shown in Figures 1 and 2 .

1. Tibetian-Tethys Zone: Most of the great Himalayan peaks of Nepal including Mt Everest belong to this zone. The rocks of the zone are shales, limestones and sandstones ranging from Lower Paleozoic to Paleocene.

2. Higher Himalayan Zone: This zone is basically composed of metamorphic rocks such as kyanite-sillimanite bearing gneisses, schists and marble with some granitic intrusions. The northern part of this zone is generally marked by normal faults.

3. Lower Himalayan Zone: This zone consists of sedimentary and metasedimentary rocks like slates, phyllites, schists, quartzites, limestones, dolomites etc., ranging from Precambrian to Eocene. There are also granitic intrusions in this zone. Its southern and northern borders are marked by the Main Boundary Thrust (MBT) and Main Central Thrust (MCT), respectively.

4. Sub-Himalayan Zone: Sub-Himalayan zone is composed of fluvial deposits of Neogene 
age with rocks of sandstones, shales, siltstones, mudstones and conglomerates. This zone is bounded to the north by Main Boundary Thrust (MBT) and to the south by the Main Frontal Thrust (MFT).

5. Terai Zone: Terai is a flat plain composed of about $1,500 \mathrm{~m}$ thick alluvial deposits. This zone represents the northern edge of the Indo-Gangetic alluvial plain and forms the southern most tectonic division of Nepal Himalaya. To the north, this zone is often delineated by Main Frontal Thrust (MFT), which is also called the Himalayan Frontal Thrust (HFT).

\section{GEOMORPHOLOGIC FEATURES}

As already stated, it is believed that the Himalaya was formed as a result of continental collision between the Indian and Eurasian plates. The Indian plate is going down (subducting), whereas the Eurasian plate is rising over the Indian plate. According to Iwata et al. (1984), Nepal Himalaya is uplifting at the rate of about $1 \mathrm{~mm} / \mathrm{yr}$. Indian plate is moving northwards at a rate of few centimeters per annum. This activity has generated a linear belt of cracks (thrusts) parallel to the Himalaya e. g. Main Central Thrust, Main Boundary Thrust and Himalayan Frontal Thrust (Fig. 2). Rocks are being crushed along these thrusts. Drainage system is almost at right angle to the thrusts. Himalayan rivers and streams have been eroding by down cutting, into comparatively soft and weak rocks since the formation of the Himalaya. Thus long and steep slopes were created in the Nepalese Mountains. Slopes in the High Himal are generally more than $40^{\circ}$. The High Mountains consists of valley bottoms and ridges which are just as steep as those of the High Himal. In the Middle Mountains, slopes of more than $30^{\circ}$ are common. Compared to the three upper zones the Siwaliks and Terai have less steep and shorter slopes. However, the Siwaliks are extremely rugged and access even by footpath is limited. Slopes are commonly $20^{\circ}$. Except some parts of Bhabar sub-zone, slopes in Terai are less than $5^{\circ}$. Although the soil erosion and landslides occur in almost all parts of the Nepalese mountains, the natural hill slopes with gradient between $30^{\circ}$ and $40^{\circ}$ are found to be most critical for failure (Dikshit, 1994).

Because the Himalaya and the Tibetan plate are being uplifted as the Indian plate thrusts beneath central Asia, enormous masses of eroded sediment are being deposited in the southern part which, over the past several million years, has become the great plains of Ganges, Indus and Brahmaputra. On a more resent time frame, the Koshi river has shifted its channel across its great alluvial fan, forming much of the Bihar state of the India, through a distance of more than $100 \mathrm{~km}$ in 250 years. There is, therefore, abundant evidence of massive erosion and regional denudation and equally massive sediment transfer and deposition that has occurred over the past million or more years.

Ives and Messerli (1989) have stated the following broad concepts concerned with the dilemmas facing geomorphic and hydrological research in the Himalayan region. (1) The Himalaya-Brahmaputra-Ganges-Indus system is one of the world's most dynamic mountain-building and sediment transfer system, processes that have continued unabated over recent geological time and will likely continue into the future. (2) These processes, the endogenous, tectonic/isostatic activity and the exogenous, climatic/weathering/hydrological ones, have created an unstable landscape of the utmost complexity. 
(3) Given the massive scale of relief, from more than $5,000 \mathrm{~m}$ below sea level to nearly $9,000 \mathrm{~m}$ above sea level, and the enormous variations in climate, vegetation and topography, and a variability of major geomorphic events in time and space, the present database is completely inadequate for determination of actual rate of activity of the various processes affecting the land surface. Thus determination of the impact of human intervention including deforestation, land use changes and manipulation of water flow and their differentiation from the natural processes as a proportion of the total rate of change on soil erosion and sedimentation, is extremely difficult.

\section{LAND USE}

Land use breakdown by physiographic zones is shown in Table 2 . As defined in the LRMP study, non-cultivated inclusions are small pockets of land close to cultivated land. They may contain barren areas, trees, shrubs or grass. At least $10 \%$ crown cover area is considered as "Forested Land", but small pockets of plantation and burned areas are also included. The "Other lands" category is the catch-all for all other land uses and may include rocky areas, lakes, ponds, water ways or settlements (MFSC, 1988).

Table. 2 Land use, 1985-86.

\begin{tabular}{|c|c|c|c|c|c|c|}
\hline Land use & $\begin{array}{l}\text { High } \\
\text { Himal }\end{array}$ & $\begin{array}{l}\text { High } \\
\text { Mountains }\end{array}$ & $\begin{array}{l}\text { Middle } \\
\text { Mountains }\end{array}$ & Siwaliks & Terai & $\begin{array}{c}\text { Total } \\
(\%)\end{array}$ \\
\hline $\begin{array}{l}\text { Cultivated } \\
\text { land }\end{array}$ & 8 & 245 & 1224 & 268 & 1308 & $\begin{array}{l}3053 \\
(21)\end{array}$ \\
\hline $\begin{array}{l}\text { Non-cultivated } \\
\text { inclusions }\end{array}$ & 2 & 147 & 667 & 58 & 124 & $\begin{array}{l}998 \\
(7)\end{array}$ \\
\hline Grass land & 885 & 508 & 279 & 16 & 58 & $\begin{array}{l}1746 \\
(12)\end{array}$ \\
\hline $\begin{array}{l}\text { Forest land/ } \\
\text { Forest plantation }\end{array}$ & 154 & 1639 & 1807 & 1438 & 474 & $\begin{array}{l}5512 \\
(37)\end{array}$ \\
\hline $\begin{array}{l}\text { Shrub lands } \\
\text { Degraded forests }\end{array}$ & 66 & 176 & 407 & 31 & 29 & $\begin{array}{l}709 \\
(5)\end{array}$ \\
\hline $\begin{array}{l}\text { Other lands } \\
\text { (Rocks, etc.) }\end{array}$ & 2234 & 245 & 59 & 75 & 117 & $\begin{array}{l}2730 \\
(18) \\
\end{array}$ \\
\hline Total & 3349 & 2960 & 4443 & 1886 & 2110 & $\begin{array}{l}14748 \\
(100)\end{array}$ \\
\hline
\end{tabular}

Source: Ministry of Forests and Soil Conservation (MFSC), Master Plan for the Forestry Sector, Nepal, Information Status and Development (1988). 


\section{SOIL EROSION}

\section{Watershed Conditions}

The watersheds of Nepal are mainly divided into four major river basins, namely: the Koshi in Eastern region, the Gandaki or Narayani in central region, the Karnali in midwest region and the Mahakali in far-western region. However, each river basin covers different physiographic zones. FAO conducted a reconnaissance inventory of the major ecological land units and a study of their watershed condition in 1980. "Watershed condition" was defined in the study as the state of soil erosion in an area in comparison to the soil erosion estimated for that area under natural or well managed conditions. Five classes of watershed condition were identified: excellent, good, fair, poor and very poor.

Shrestha (1983) pursued the FAO study further by ranking the districts with respect to watershed condition. The average watershed condition of the districts were described as good, fairly good, marginal, poor and very poor (Table 3). Twenty-five out of 75 districts of Nepal were considered to have marginal to very poor average watershed condition.

Table 3. Distribution of districts according to average watershed condition.

\begin{tabular}{lrc}
\hline $\begin{array}{l}\text { Average } \\
\text { watershed } \\
\text { condition }\end{array}$ & $\begin{array}{l}\text { Numerical value } \\
\text { of ranking points }\end{array}$ & $\begin{array}{l}\text { Number of } \\
\text { districts }\end{array}$ \\
\hline Good & $<500$ & 25 \\
Fairly good & $500-1500$ & 25 \\
Marginal & $1500-3000$ & 13 \\
Poor & $3000-4500$ & 5 \\
Very poor & $>4500$ & 7 \\
\hline Source: Ministry of Forests and Soil Conservation (MFSC), Master Plan for the \\
\multicolumn{2}{c}{ Forestry Sector, Nepal, Soil Conservation and Watershed Management } \\
$\quad$ Plan (1988).
\end{tabular}

\section{Erosion Rate}

Denudation of Nepalese mountains due to soil erosion, whether natural or accelerated has been a serious concern for the natural scientist. According to Joshi (1996), soil loss studies carried out by different experts in the different parts of Nepal have estimated average soil erosion rates (tons per hectare per year) as follows:

$\begin{array}{ll}\text { Siwaliks } & 20-40 \\ \text { Mahabharat Hill } & 30-40 \\ \text { Middle Hills } & 20-50\end{array}$

Similarly, soil erosion rates (tons per hectare per year) by land use are estimated as follows :

$\begin{array}{lc}\text { Well managed forest land } & 5-10 \\ \text { Well managed rice terraces } & 5-15 \\ \text { Poorly managed sloping terraces } & 20-100 \\ \text { Degraded range land } & 10-200\end{array}$




\section{Factors Causing Accelerated Soil Erosion}

Main factors causing accelerated soil erosion in Nepal are pointed out as follows:

Natural factors:

1. Young, unconsolidated and fragile mountains.

2. Active tectonic activities.

3. Rugged mountain topography with steep slopes.

4. Anomalous climatic conditions (e. g. high intensity rainfall).

Manmade impacts:

1. Deforestation:

Nepalese watersheds vary in elevation and have diverse environment. These watersheds therefore present a mosaic of diverse vegetation types. But, number of rare and endangered species is increasing due to loss of their habitat.

Heavy economical pressure is being exerted on the forests of Nepal by the increasing population. The people depend on the forests for fuel wood, constructional timber and other minor forest products such as fodder for their cattle. They also use forest for grazing to maintain a large number of livestock which are essential for supplying manure for agricultural crops, draft power for ploughing, milk, meat and wool. As a result of this pressure, the forests have been reduced in area and depleted of trees. Over large areas of the middle hills nearly all the natural forests have been removed and replaced by cultivation. What forest remains is confined to small patches, and often the only woody vegetation left, is in the form of shrubbery such as Barberis sp., Pyracantha crenulata Rosa, Rubus and Rhus species. In the Terai there is also large areas of natural Shorea robusta (SAL) forests having been cleared for cultivation in the last four decades. Thus, decreeing vegetative cover allowed the increase of surface run off causing accelerated erosion and reduced the stability of mountain slopes.

2. Inappropriate land use:

Conversion of forerst land into agricultural land, even in the steep slopes is one of the main cause of accelerated erosion. Land use pattern is changing without considering the land capability and its stability.

3. Overgrazing of forest and pasture land by the cattle.

4. Construction:

Construction of infrastructures, such as roads, irrigation canals and dams in the fragile mountain sides, without detail investigations on different aspects and without considering appropriate erosion control measures.

\section{MASS WASTING AND SEDIMENT DISASTER}

Nepal is prone to natural disaster and each year at least 400 to 500 lives and property worth several million dollars are lost (Sharma, 1988). Sediment disaster caused by mass wasting is frequent in Nepal. During monsoon season, high intensity rainfall occurs in the mountain sides, which cause accelerated soil erosion. Numerous slope failures, landslides and debris flows occur in the mountains together with sudden flooding in the plain area, resulting in disasters. Such a disaster causes loss of life, destroys many bridges, roads, irrigation channels and power intakes located in the mountains. At the same time, flood submerges many villages and destroys agricultural crops on the plain. 
Such disasters are associated with Himalayan geomorphology. There are historical evidence of past disasters. One of the most spectacular geomorphic events occurred in historic times in the Nepal Himalaya, was the outburst of a moraine-dammed lake behind Mt Machhapuchhre, 600-800 years ago. This caused a flood surge down the Setikhola depositing $5.5 \mathrm{~km}^{3}$ of debris in the Pokhara valley, and damming Lake Phewa. Another geomorphic event was a giant landslide in the Lantang Himal, Nepal, which generated fused rock (frictionite) along its sliding surface, displaced approximately $10 \mathrm{~km}^{3}$ of debris through a vertical distance of up to $2,000 \mathrm{~m}$. This occurred approximately 25,000 years ago (Ives and Messerli, 1989).

\section{Disaster of 1993}

A recent disaster due to soil erosion and flooding occurred in July 1993, causing the worst disaster in Nepalese history. Very heavy rainfall of $540 \mathrm{~mm}$ in a day, the maximum ever recorded in Nepal, occurred in some parts of the central and eastern regions from 19 to 21 July, 1993. This event caused numerous landslides, land collapses, debris flows and flooding. Another deluge occurred on 8 and 9 August, about three weeks after the initial heavy rain. The peak flood levels were highest in many rivers, even exceeding the design water level and causing complete destruction of barrages, embankments and other structures (DPTC, 1994b). Forty-eight out of 75 districts of Nepal were affected by landslides and floods in 1993, whereas 44 out of 48 affected districts were severely stricken by the July disaster. Slope failure and landslides occurred at many places on the hilly slopes and debris flows occurred along all streams. About 500,000 people belonging to 84,150 families were affected. 1,475 persons were killed and missing. 39,694 houses were damaged. Development infrastructures damaged include $367 \mathrm{~km}$ road, 277 bridges, 633 public buildings, Kulekhani hydropower project and Bagmati irrigation barrage. In agriculture sector, about 60,000 hectares of arable land, thousands of farmer managed irrigation schemes and 67 large and small irrigation projects were severely damaged. A total of 25,388 heads of livestock were also killed (DPTC, 1994a; MOH, 1994).

\section{DISCUSSION AND CONCLUSION}

There is a great diversity in terms of physiography, geology, climate and vegetation of Nepal. These natural factors have created favorable conditions for soil erosion and sediment disasters, caused mainly by slope failure, landslides, debris flows and bank erosion. Geologically, Nepalese mountains are very young, unconsolidated and fragile. Rugged mountains with steep slopes are likely to erode or fail during heavy rainfall or earthquakes. Monsoon rainfalls are a common phenomena in Nepal. Thus, geomorphic processes like soil erosion, slope failure, landslides, debris flows, glacial lake outburst and river bank erosion have been continuing since the formation of Himalaya. In spite of this, people have been living in the mountains with peace and prosperity, for thousands of years. A balance between human activities and the natural support system was maintained until the $1960 \mathrm{~s}$. Since 1960, however, the increase in both human and livestock population has drastically changed the land use picture of Nepal. With the conversion of large areas of forests to farms, the production from the remaining forests is less than the rate of consumption of forest products and this is resulting in over-cutting and further 
deforestation (MFSC, 1988). Thus, more surface soil of the mountains has become exposed due to the loss of vegetative cover and has become liable to erosion. The deterioration of land productivity due to the increasing rate of loss of top soil is a key indicator of ecological imbalance. Due to loss of vegetative cover and consequent soil erosion, general conditions of the watersheds have been rapidly deteriorating. Improper land use practices, uncontrolled and excessive grazing, construction of infrastructures such as roads, irrigation canals, and dams in the fragile landscape, without considering adequate conservation measures, have fueled the continuing soil erosion and environmental deterioration. Thus, human activities have caused the disturbance in the regime of nature and intern have caused destruction or damaging effects to human life and property. Hence, conservation of nature has become more vital for existence and development of the people living in a country like Nepal.

It is realized that soil erosion control is one of the urgent needs for sustainable development. Soil erosion or sediment disasters due to natural processes will likely continue into the future, but human contribution in accelerating these processes should be minimized. Although various soil conservation measures and watershed management programs have been implemented since 1974, to minimize erosion and to reduce disaster potential, these problems are still critical. Lack of site specific as well as economically feasible appropriate technology, inappropriate land use and insufficient resources are the main problems in implementing erosion control measures. Research works on various aspects of erosion and it's control in the Nepalese mountains are limited. Modern technology of erosion control, developed in different countries of the world to suite their own environmental and socio-economical condition, can not be applied directly in Nepal. International cooperation is expected in the research, appropriate technology transfer and human resource development to develop Nepal as a less hazardous country in the future.

\section{REFERENCES}

Bhatta, B. 1993 Comment on Economic and Environmental Management of Forests in Nepal: Issues and Problems. Published in "Environment and Sustainable Development Issues in Nepalese Perspective". Nepal Foundation for Advanced Studies. pp. 72-75

CBS 1994 Statistical Pocket Book, Nepal, 1994. Central Bureau of Statistics, National Planning Commission Secretariat, His Majesty's Government of Nepal

Dikshit, A. M. 1994 Landslide Hazards in Nepal: Causes and Assessment. Water Nepal, Vol. 2. pp. 2-12

DPTC 1994a Annual Disaster Review 1993. Water Induced Disaster Prevention Technical Center (DPTC) Lalitpur, Nepal

DPTC 1994b Photo Album of Disaster of July 1993 in Nepal. Water Induced Disaster Prevention Technical Center (DPTC) Lalitpur, Nepal

DPTC 1995 Annual Disaster Review 1994. Water Induced Disaster Prevention Technical Center (DPTC) Lalitpur, Nepal

DSC 1995 Soil Conservation and Watershed Management in Nepal: A Brief Introduction. Department of Soil Conservation, Kathmandu, Nepal

Ganser, A. 1964 Geology of the Himalayas, Interscience, New York, pp. 289

HMG 1985 Physiographic Map of Nepal. Department of Survey, His Majesty's Government of Nepal

Ives, J. D. and Messerli, B. 1989 The Himalayan Dilemma Reconciling development and conservation. pp. 93-122

Iwata, S., Sharma, T. and Yamanaka, H. 1984 A preliminary report of central Nepal and Himalayan uplift, Journal Nepalese Geological Society. 4: 141-49 
Joshi, J. 1996 Soil Erosion in Nepal: A Challenging Problem. GORAKHAPATRA Daily (A National News Paper of Nepal), January, 1996. Kathmandu, Nepal

Kobayashi, S., T. Ito, R. Yattabe, and J. Takahashi 1995 Natural Disasters Caused by Heavy Rainfall in Nepal at July, 1993. Journal of Japan Society for Natural Disaster Science. Vol. 14. No. 2

LRMP 1986 Summary report. Land Resource Mapping Project. Nepal

MFSC 1988 Master Plan for the Forestry Sector Nepal: Soil conservation and Watershed Management Plan. Ministry of Forests and Soil Conservation (MFSC), HMG Nepal

MOH 1994 Disaster of July 1993 in Nepal. Ministry of Home/HMG Nepal in cooperation with Water Induced Disaster Prevention Technical Center (DPTC) Lalitpur, Nepal

Nelson, D., P. Laban, B. D. Shrestha and G. P. Kandel 1980 A reconnaissance inventory of the major ecological land units and their watershed condition in Nepal. Department of soil conservation and watershed management, Kathmandu. FAO consultant report NEP/74/020

Ramsay, W. J. H. 1986 "Erosion problems in the Nepal Himalay-an overview" in S. C. Joshi (ed.), Nepal Himalaya: Geological Perspectives. Himalayan Research Group. Nainital, UP, India

Sharma, C. K. 1988 Natural Hazards and Man Made Impacts in the Nepal Himalaya. Mrs. Puspa Sharma, Kathmandu

Shrestha B. D. et al. 1983 Watershed condition of the districts of Nepal. Department of soil conservation and watershed management. FAO Field document no. 9, Kathmandu

Sthapit, K. M. 1995 Soil Conservation Research and Demonstration: Its Field Implications. Department of Soil Conservation, Kathmandu, Nepal 